\title{
GH action influences adipogenesis of mouse adipose tissue-derived mesenchymal stem cells
}

\author{
Nicoleta C Olarescu ${ }^{1,2}$, Darlene E Berryman ${ }^{3,4}$, Lara A Householder ${ }^{3,4}$, \\ Ellen R Lubbers ${ }^{3}$, Edward O List ${ }^{3}$, Fabian Benencia ${ }^{4}$, John J Kopchick ${ }^{3,4}$ \\ and Jens Bollerslev ${ }^{1,2}$ \\ ${ }^{1}$ Section of Specialized Endocrinology, Department of Endocrinology, Oslo University Hospital, \\ Rikshospitalet, PO Box 4950, N-0424 Oslo, Norway \\ ${ }^{2}$ Faculty of Medicine, University of Oslo, Oslo, Norway \\ ${ }^{3}$ Edison Biotechnology Institute, Ohio University, Athens, Ohio, USA \\ ${ }^{4}$ Heritage College of Osteopathic Medicine, Ohio University, Athens, Ohio, USA
}

Correspondence should be addressed to N C Olarescu

Email

nicola@ous-hf.no

\begin{abstract}
GH influences adipocyte differentiation, but both stimulatory and inhibitory effects have been described. Adipose tissue-derived mesenchymal stem cells (AT-MSCs) are multipotent and are able to differentiate into adipocytes, among other cells. Canonical Wnt/ $\beta$-catenin signaling activation impairs adipogenesis. The aim of the present study was to elucidate the role of GH on AT-MSC adipogenesis using cells isolated from male GH receptor knockout (GHRKO), bovine GH transgenic (bGH) mice, and wild-type littermate control (WT) mice. AT-MSCs from subcutaneous (sc), epididiymal (epi), and mesenteric (mes) AT depots were identified and isolated by flow cytometry (Pdgfr ${ }^{+} \mathrm{Sca} 1^{+} \mathrm{Cd} 45^{-} \mathrm{Ter} 119^{-}$cells). Their in vitro adipogenic differentiation capacity was determined by cell morphology and real-time RT-PCR. Using identical in vitro conditions, adipogenic differentiation of AT-MSCs was only achieved in the sc depot, and not in epi and mes depots. Notably, we observed an increased differentiation in cells isolated from sc-GHRKO and an impaired differentiation of sc-bGH cells as compared to sc-WT cells. Axin2, a marker of Wnt/ $\beta$-catenin activation, was increased in mature sc-bGH adipocytes, which suggests that activation of this pathway may be responsible for the decreased adipogenesis. Thus, the present study demonstrates that i) adipose tissue in mice has a well-defined population of $P d g f r \alpha{ }^{+} \mathrm{Sca}^{+}{ }^{+} \mathrm{MSCs}$; ii) the differentiation capacity of AT-MSCs varies from depot to depot regardless of GH genotype; iii) the lack of $\mathrm{GH}$ action increases adipogenesis in the sc depot; and iv) activation of the $W n t / \beta$-catenin pathway might mediate the GH effect on AT-MSCs. Taken together, the present results suggest that GH diminishes fat mass in part by altering adipogenesis of MSCs.
\end{abstract}

\section{Key Words}

- growth hormone

- adipose tissue-derived mesenchymal stem cells

- adipogenesis

- Wnt/ $\beta$-catenin signaling

\section{Introduction}

Recent studies have indicated that healthy adipose tissue (AT) expansion, especially of the subcutaneous (sc) fat depot, is essential for protecting against ectopic fat deposition in muscles and the liver and against resulting insulin resistance (Hocking et al. 2013, Shulman 2014). AT expansion is achieved by increasing the size of individual 
cells (hypertrophy) or by recruiting new adipocytes from the resident pool of progenitors (hyperplasia) (Rosen \& Spiegelman 2014). Growth hormone (GH) decreases fat mass, and this effect is thought to be mediated by the GH stimulation of lipolysis and inhibition of lipogenesis (Moller \& Jorgensen 2009). Indeed, both in mice and in humans, GH deficiency has been shown to lead to increased fat mass, whereas GH excess, such as in acromegaly, is associated with a decrease in fat mass (Berryman et al. 2004, Jorgensen et al. 2011, Olarescu et al. 2012). In contrast to the well-known lipolytic action, $\mathrm{GH}^{\prime} \mathrm{s}$ effect on adipocyte differentiation is more controversial and difficult to reconcile, particularly because the effects seen in cell lines differ from observations in primary cells (Morikawa et al. 1982, Green et al. 1985, Doglio et al. 1986, Hausman \& Martin 1989, Corin et al. 1990, Clarkson et al. 1995, Wabitsch et al. 1995, 1996a,b, Flint et al. 2006, Zhao et al. 2014). For example, activation of one of the main GH dependent intracellular signaling proteins, STAT5, has been shown to decrease differentiation in primary rat preadipocytes (Hansen et al. 1998, Richter et al. 2003), but it has also been shown to increase differentiation in mouse preadipocyte cell lines (3T3-L1, 3T3-F442A) (Yarwood et al. 1999, Shang \& Waters 2003, Stewart et al. 2004). When interpreting the discrepant results of the effect of GH on adipogenesis, one should take into account that: i) genuine variance exists between the response of primary cells and the response of cell lines to GH stimulation; ii) pools of cells at different stages of differentiation were studied; and iii) the experiments were performed under serum-containing conditions that may have obscured GH's effects by making cells refractory to GH stimulation.

Mesenchymal stem cells (MSCs) are multipotent cells that are present in adult marrow. They can replicate as undifferentiated cells and have the potential to differentiate to lineages of mesenchymal tissues, including fat, bone, and cartilage. The self-renewal and differentiation of MSCs are regulated in part by the Wnt $/ \beta$-catenin signaling pathway. That is, activation of $\mathrm{Wnt} / \beta$-catenin signaling decreases the adipogenic potential of MSCs (Ross et al. 2000, Lowe et al. 2011). Although MSCs have primarily been described in bone marrow, they are present in and can be isolated from several organs, including AT (Pittenger et al. 1999, Zuk et al. 2002). Platelet-derived growth factor receptor, $\alpha$ polypeptide ( $P d g f r \alpha)$ and stem cell antigen 1 (Sca1) have recently been identified as being selective markers of mouse MSCs. Pdgfr ${ }^{+} S c a 1^{+}$MSCs have augmented growth potential and robust tri-lineage differentiation as compared to standard culture-selected MSCs (Houlihan et al. 2012). In addition, the selective isolation of
MSCs by flow cytometry avoids cellular contamination that can complicate other culture methods.

In the present study, we hypothesized that GH action influences the fate of AT-derived MSCs (AT-MSCs) by decreasing their differentiation potential toward adipocytes. To avoid the unspecific effects of the growth factors that are present in fetal bovine serum (FBS) and to study how these cells behave ex vivo, we used two genetically engineered mouse lines with decreased or increased GH action. More specifically, we used a dwarf mouse line that is completely insensitive to $\mathrm{GH}$ (GH receptor knockout (GHRKO) mice) and a giant mouse line with extra copies of the bovine GH gene (bovine GH transgenic (bGH) mice). Thus, our primary aim was to elucidate the role of GH on AT-MSC adipogenesis using cells isolated from these mice and control littermates.

\section{Materials and methods}

\section{Animals}

Four-month-old male GHRKO, bGH, and WT mice were used. The production of these mice has been previously described (Zhou et al. 1997, Berryman et al. 2004). Mice were either produced on a pure C57BL/6J background or backcrossed more than ten generations into C57BL/6J mice, and they were bred in the animal facility at the Edison Biotechnology Institute, Ohio University, Athens, $\mathrm{OH}$, USA. All mice were kept under specific pathogen-free conditions on a $14 \mathrm{~h}$ light:10 h darkness cycle; they were allowed to consume normal chow (Prolab RMH 3000 LabDiet; PMI Richmond, Richmond, IN, USA) and water ad libitum. Procedures were approved by the Ohio University Animal Care and Use Committee.

\section{Body composition}

Fat, lean, and fluid mass were analyzed with a quantitative NMR apparatus (Minispec, Bruker Optics, Billerica, MA, USA) according to a previously described protocol (List et al. 2009).

\section{White adipose tissue depot samples}

All of the mice were killed by cervical dislocation. Subcutaneous/inguinal (sc) and all intra-abdominal depots - epididymal (epi), mesenteric (mes), and retroperitoneal (retro) - were collected using sterile dissection techniques.

Published by Bioscientifica Ltd. 


\section{Isolation of adipose tissue stromal vascular fractions}

In order to obtain a sufficient number of cells for further in vitro culture, different white adipose tissue (WAT) depots from three mice were collected together and washed three times with fresh PBS containing 1\% antibiotic-antimycotic (cat. no. 15240-062, Gibco). The tissue was minced and digested with collagenase solution - HBSS with Ca and $\mathrm{Mg}$ (cat. no. 14025092, Gibco) supplemented with $2 \mathrm{mg} / \mathrm{ml}$ collagenase, type 1 (cat. no. LS004196, Worthington Biochemical Corp., Lakewood, NJ, USA), $3 \mathrm{mM} \mathrm{CaCl}_{2}$, and $2 \% \mathrm{BSA}$ - for $60 \mathrm{~min}$ at $37^{\circ} \mathrm{C}$ and $150-250$ r.p.m. on a horizontal shaker. The mature adipocyte fraction was removed, and the stromal vascular fraction (SVF) suspension was filtered through a $70 \mu \mathrm{m}$ sterile filter and spun down by centrifugation at $280 \boldsymbol{g}$ for $5 \mathrm{~min}$ at $4{ }^{\circ} \mathrm{C}$. The pellet was resuspended by tapping, and the red blood cells were lysed in the suspension by adding $1 \mathrm{ml}$ of ice-cold sterile $\mathrm{H}_{2} \mathrm{O}$ for $6 \mathrm{~s}$ as previously described (Houlihan et al. 2012). The SVF was spun down again by centrifugation, and the pellets were resuspended in fresh PBS.

\section{Fluorescence-activated cell sorting}

After being incubated with specific antibodies, SVF samples were analyzed and sorted on a FACSAria flow cytometer with FACSDiva software (Becton Dickinson, San Jose, CA, USA). Two surface markers for mouse AT-MSC (Pdgfr $\alpha$ and Sca1) and two negative surface markers (Cd45 and Ter119) were used to identify and sort a pure population of mouse AT-MSCs, following a previously validated protocol (Houlihan et al. 2012). The specific fluorochrome-conjugated MABs (1:100 dilution) used were from eBioscience (San Jose, CA, USA) (Table 1). Output data was recorded by the FACS Diva software.

\section{Cell culture}

Sufficient cells were obtained for in vitro experiments from the sc, epi, and mes depots but not from the retro depot. The fluorescence-activated cell sorted (FACS) populations of AT-MSCs were seeded at a density of 5000 cells $/ \mathrm{cm}^{2}$ in growth medium - DMEM-F12 (cat. no. 21885-108, Gibco), 10\% FBS (cat. no 12662-029, Gibco), 2 mM glutamine (cat. no. 35050-038, Invitrogen), and 1\% antibioticantimycotic - and cultured for two passages. The cells were then seeded at a density of 40000 cells/well in 12-well plates (Costar, Cambridge, MA, USA) and maintained in a humidified incubator at $37^{\circ} \mathrm{C}$ with $5 \% \mathrm{CO}_{2}$. Confluent cultures were induced to differentiate using differentiation media - DMEM-F12, 0.5 mM IBMX (cat. no. I5879, Sigma), $1 \mu \mathrm{M}$ dexamethasone (cat. no. D4902, Sigma), $0.2 \mathrm{mM}$ indomethacin (cat. no. I7378-56, Sigma), and $10 \mu \mathrm{g} / \mathrm{ml}$ insulin (cat. no. I9278, Sigma) - for 7 days.

Pictures were taken for visualization of the lipid droplet formation, and the cells were lysed with QIAzol lysis reagent (Qiagen).

\section{Real-time RT-PCR}

RNA was isolated using an ethanol precipitation method. cDNA was synthesized with Maxima First Strand cDNA Synthesis Kits (cat. no. K1642, Thermo Scientific, Waltham, MA, USA), and quantitative real-time RT-PCR was performed with Maxima SYBR Green/Fluorescein qPCR Master Mix (cat. no. K0242, Thermo Scientific). Data were normalized to ribosomal protein S3 (Rps3), which is one of the most stable housekeeping genes for WAT (Lubbers et al. 2013). Primer sequences are listed in Table 2.

\section{Statistical analysis}

Data are expressed as means \pm s.E.m. First, one-way ANOVA was performed to assess the total variability within the mice or cells data. Then, two-tailed unpaired Student's sample $t$-tests were used to evaluate differences between genetically engineered mouse lines and WT mice and between cells isolated from these mouse lines and control littermates.

Table 1 Antibodies used for primary isolation and immunophenotyping

\begin{tabular}{|c|c|c|c|}
\hline Protein and fluorochrom & eBioscience cat. no. & Clone & Isotype \\
\hline SCA1: Alexa Fluor 700 & $56-5981-80$ & D7 & Rat IgG2a $\kappa$ \\
\hline PDGFR $\alpha:$ PE & $12-1401-81$ & APA5 & Rat IgG2a $\kappa$ \\
\hline CD45: APC-eFluor 780 & $47-0451-80$ & 30-F11 & Rat lgG2a $\kappa$ \\
\hline TER119: PerCP-Cyanine5.5 & $45-5921-80$ & TER 119 & Rat IgG2b $\kappa$ \\
\hline Isotype Alexa Fluor 700 & $56-4301-80$ & eBRG1 & Rat IgG1 $\kappa$ \\
\hline Isotype PE & $12-4301-81$ & eBRG1 & Rat IgG1 $\kappa$ \\
\hline Isotype APC-eFluor 780 & $47-4714-80$ & P3.6.2.8.1 & Mouse $\lg G 1 \kappa$ \\
\hline Isotype PerCP-Cyanine5.5 & $45-4301-80$ & eBRG1 & Rat IgG1 $\kappa$ \\
\hline 7-AAD viability staining solution & $00-6993-50$ & - & - \\
\hline
\end{tabular}


Table 2 Real-time RT-PCR primer pairs. All of the primers are listed $3^{\prime}$ to $5^{\prime}$

\begin{tabular}{|c|c|c|}
\hline Gene & Primers & $\begin{array}{l}\text { Product } \\
\text { length }\end{array}$ \\
\hline Rps3 & $\begin{array}{l}\text { F: ATCAGAGAGTTGACCGCAGTT } \\
\text { R: AATGAACCGAAGCACACCATA }\end{array}$ & 183 \\
\hline Ppary & $\begin{array}{l}\text { F: GGGATATTTTTGGCATACTCTG } \\
\text { R: AAAGACAACGGACAAATCAC }\end{array}$ & 195 \\
\hline Adiponectin & $\begin{array}{l}\text { F: CTCTCCTGTTCCTCTTAATCCT } \\
\text { R: ACCAAGAAGACCTGCATCTC }\end{array}$ & 218 \\
\hline Fabp4 & $\begin{array}{l}\text { F: ACACCGAGATTTCCTTCAAACTG } \\
\text { R: CCATCTAGGGTTATGATGCTCTTC }\end{array}$ & 88 \\
\hline Axin2 & $\begin{array}{l}\text { F: CGCCAACGACAGCGAGTT } \\
\text { R: CGGTAAGGAGGGACTCCATCTA }\end{array}$ & 90 \\
\hline
\end{tabular}

$F$, forward; $R$, reverse.

\section{Results}

\section{Body weight and body composition}

There was a significant association between genotype and body weight, fat, lean, and fluid mass. bGH mice had significantly increased total body weight vs WT and GHRKO mice $(44.5 \pm 4.0 \mathrm{~g}$ vs $28.66 \pm 2.1 \mathrm{~g}$ and $13.5 \pm 1.7$ respectively, $P<0.001)$. As expected, GHRKO mice had the lowest total body weight but the highest percentage of body fat (Fig. 1).

bGH mice had both increased lean mass $(81.2 \pm 1.5 \mathrm{vs}$ $65.4 \pm 2.5 \%, P<0.001)$ and fluid mass $(16.8 \pm 0.7$ vs $15.0 \pm$ $0.4 \%, P<0.01)$ as compared to GHRKO mice, whereas no significant differences were observed for lean and fluid mass when the mice were compared to WT (data not shown).

\section{Selective isolation of Pdgfra ${ }^{+} \mathrm{Sca}^{+}{ }^{+}$cells from different AT depots using flow cytometry}

Using a recently described protocol (Houlihan et al. 2012), we identified and sorted a population of mouse AT-MSCs on the basis of their positive surface markers of Pdgfr $\alpha$ and Sca1 and their lack of Cd45 and Ter119, two markers of hematopoietic stem cells. The algorithm used is presented in Fig. 2. The percentage of $\mathrm{Pdgfr \alpha}{ }^{+} \mathrm{Sca} 1^{+}$cells showed a wide variability within each mouse genotype (data not shown). However, a well-delimited population of cells that complies with the AT-MSC criteria was identified and sorted (Fig. 2D).

\section{Adipogenic differentiation of WT Pdgfra ${ }^{+}$Sca1 ${ }^{+}$AT-MSCs}

Adipogenesis was achieved only in the cells derived from the sc depot in all of the genotypes. Cells from the epi and mes depots showed impaired differentiation ability, even when we used in vitro conditions that were identical to those for the sc depot (Fig. 3A). When stimulated to differentiate, none of the other depots showed increased Ppary gene expression (Fig. 3A), and very few epi cells presented lipid accumulation (data not shown), although a slight increase in adiponectin and Fabp4 gene expression was observed (Fig. 3B and C). Consequently, the assessment of the difference in the adipogenetic ability among different genotypes was performed just for the sc depot.

\section{In vitro culture and adipogenic potential of GHRKO, bGH,} and WT AT-MSCs from sc depot

As shown in Fig. 4A, the overnight cell culture of sorted AT-MSCs led to the cells attaching to the plastic surface, and no cell death was observed in the media. The cells gradually acquired a fibroblastic appearance and divided.
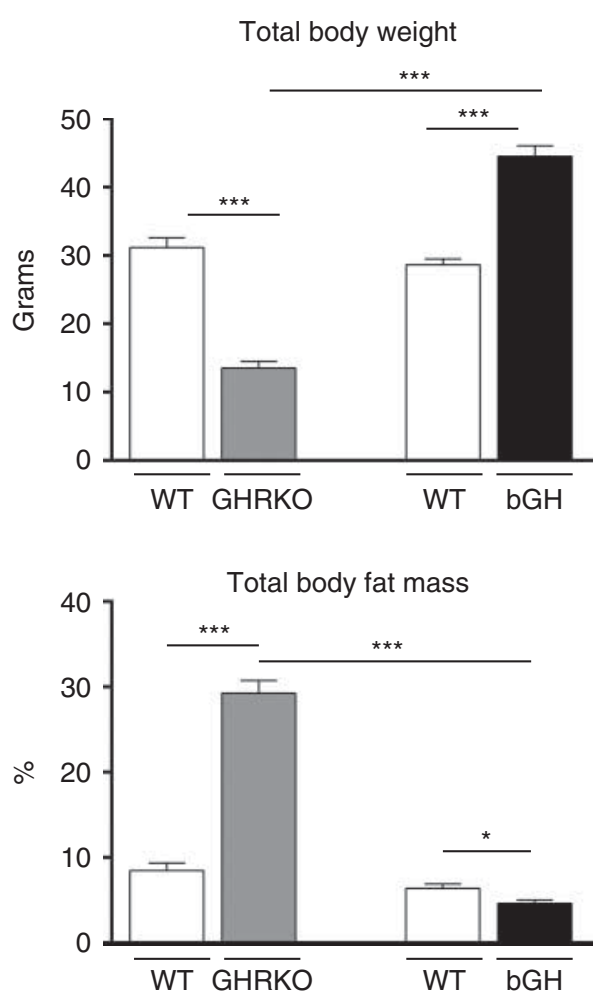

Figure 1

Total body weight and fat mass in 4-month-old male GHRKO, bGH, and WT mice. GHRKO mice had decreased total body weight but a higher percentage of body fat vs both WT and bGH mice. bGH mice had increased total body weight but a lower percentage of body fat vs both WT and GHRKO mice. No differences were observed between the different genotypes of WTs. Data are presented as means \pm s.E.M. WT, wild-type littermate control mice; GHRKO, growth hormone receptor knockout mice; bGH, bovine growth hormone transgenic mice. ${ }^{*} P<0.05,{ }^{*} * P \leq 0.001$.

Published by Bioscientifica Ltd 
A

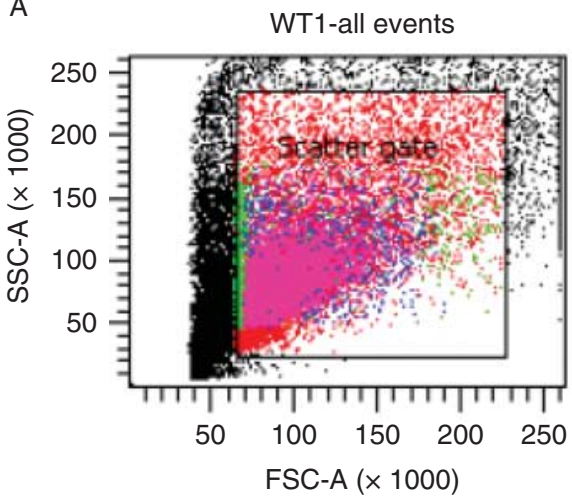

C

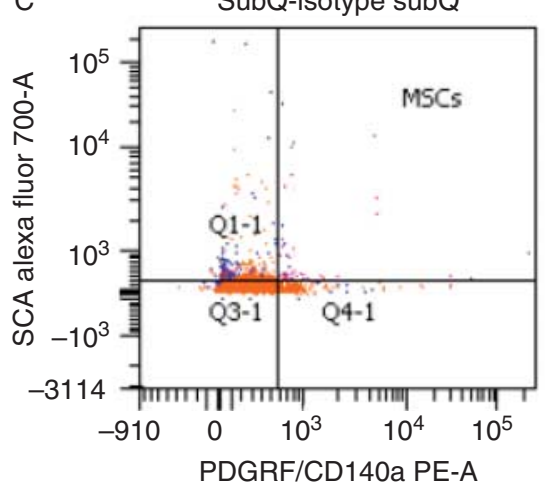

B

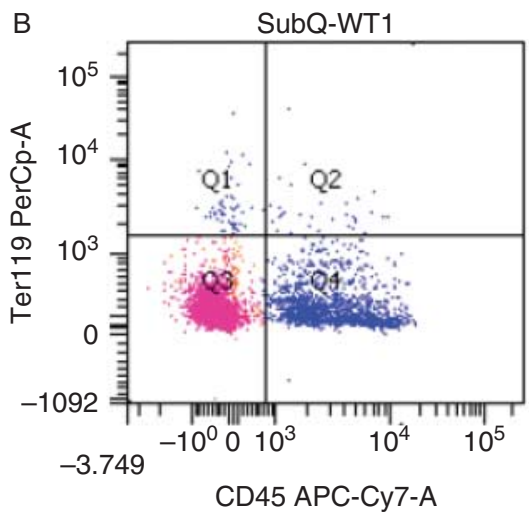

D

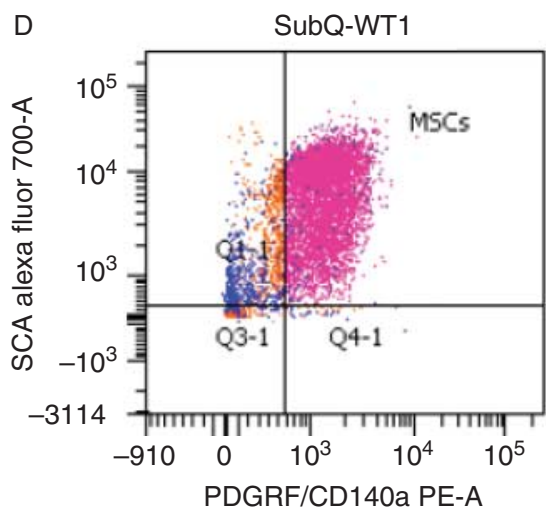

Figure 2

Fluorescence-activated cell sorting algorithm of AT-MSCs. First, a scatter gate was defined to account for cell debris and aggregates (A). Second, a population of cells negative for markers of hematopoietic lineage

No phenotypic difference was observed among the GHRKO, bGH, and WT cells. The cells were stimulated to undergo adipogenic differentiation when $100 \%$ confluence was achieved. Upon differentiation, sc AT-MSCs from all of the genotypes showed increases in Ppary, Fabp4, and adiponectin, which are markers for adipogenesis (Fig. 4B). Moreover, the GHRKO cells revealed the highest amount of lipid accumulation (Fig. 4B) and the highest mRNA levels for the adipogenic markers. Conversely, bGH cells showed less lipid accumulation and lower levels of Ppary, adiponectin, and Fabp4 mRNA as compared to WT and GHRKO cells (Fig. 4B). We also observed that lipid droplets in GHRKO cells were smaller and had a multilocular appearance as compared to those in WT and bGH cells (Fig. 4B).

\section{Activation of $\mathrm{Wnt} / \boldsymbol{\beta}$-catenin is associated with decreased adipogenesis of bGH cells}

Activation of the Wnt/ $\beta$-catenin pathway has been shown to lead to decreased adipogenesis (Ross et al. 2000, Christodoulides et al. 2009) (Fig. 5A). Thus, we determined

(Q3, Cd45 ${ }^{-} \mathrm{Ter} 19^{-}$) was separated (B). Finally, a population of cells positive for markers of mouse MSCs $\left(\operatorname{Pdgrf} \alpha^{+} \mathrm{Sca}^{+}\right)$that were not present with isotype control antibodies was identified (C) and sorted (D).

Axin2 mRNA levels as a marker for the activation of Wnt/ $\beta$-catenin. Axin2 increased during adipogenesis of WT and bGH cells but not in GHRKO cells (Fig. 5B). Moreover, the bGH cells showed a significantly higher expression of Axin2 vs WT cells, which suggests that the impairment of adipogenesis may be mediated by increased Wnt/ $\beta$-catenin activity.

\section{Discussion}

In the present study, we isolated a population of AT-MSCs $\left(\right.$ Pdgfr ${ }^{+} \mathrm{Sca}^{+} \mathrm{Cd} 45^{-} \mathrm{Ter}_{119^{-}}$cells) from different depots of dwarf GHRKO, giant bGH, and WT mice by flow cytometry. Furthermore, we cultured and assessed the adipogenic potential of the isolated cells based on the hypothesis that GH influences adipogenesis of mouse AT-MSCs. We found that the expression of key adipogenic transcriptional markers is higher in sc adipocytes differentiated from GHRKO and lower in sc cells differentiated from bGH as compared to WT cells. Thus, GH appears to play an important role by inhibiting the adipogenesis of 

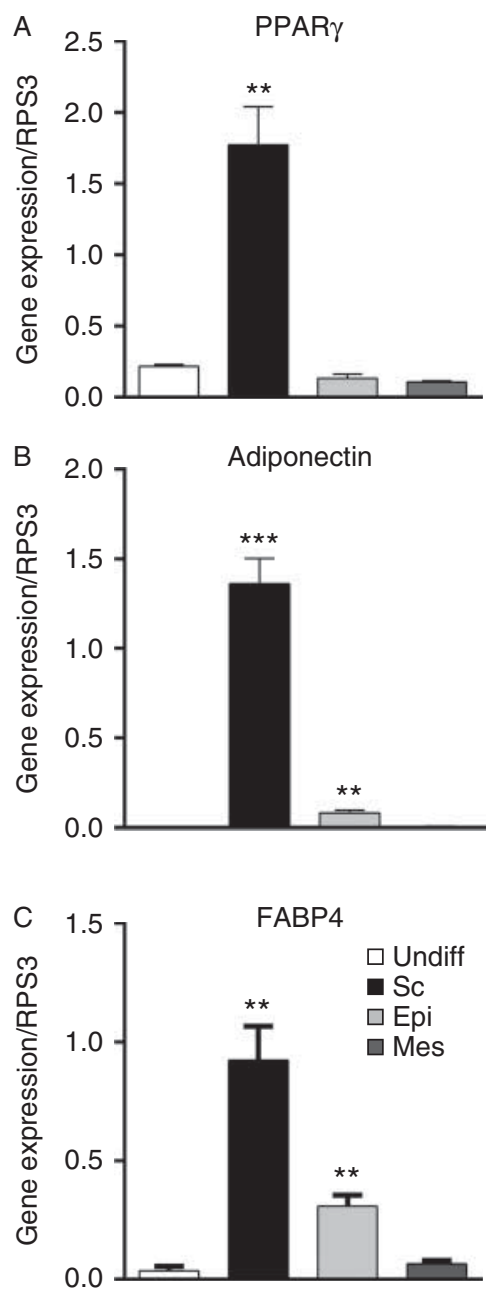

Figure 3

Different adipogenic potential of FACS sorted WT AT-MSCs. Adipogenesis was achieved in the sc depot but not in the epi and mes depots. Data are presented as means \pm S.E.M. Undiff, undifferentiated; sc, subcutaneous; epi, epididymal; mes, mesenteric. ${ }^{* *} P \leq 0.01,{ }^{* *} P \leq 0.001$ vs undifferentiated control.

sc AT-MSCs. We also demonstrated that AT-MSCs isolated from various depots have different adipogenic potential. More specifically, the present data indicate that only the cells isolated from the sc depot achieve a mature adipocyte phenotype in vitro. Finally, we suggested that the decreased adipogenesis of bGH cells might be attributed to an increase in Wnt/ $\beta$-catenin signaling.

In a recent study, SVFs isolated from the sc depots of 20-month-old GHRKO mice were found to have greater differentiation capacity as compared to controls (Stout et al. 2014). However, SVFs are a mixture of cells that, in addition to AT-MSCs, contain preadipocytes at different stages of commitment, fibroblasts, leukocytes, epithelial cells, endothelial cells, and moreover, other cells that comprise the vasculature and nerve tissue (Cawthorn et al. 2012). Thus, contamination of the in vitro culture with non-adipogenic cells may have altered the responses of the adipogenic cells. To remove the undesirable effects of cellular contamination, we decided to selectively isolate AT-MSCs by flow cytometry. AT-MSCs are a functionally distinct subpopulation of SVFs (Cawthorn et al. 2012). The most widespread technique used to distinguish between SVFs and AT-MSCs is assaying for cell surface specific markers. Therefore, we isolated mouse AT-MSCs on the basis of their positive expression of Pdgfr $\alpha$ and Sca1, two known markers of AT-MSCs (Houlihan et al. 2012). Importantly, we sorted a pure population of AT-MSCs, because Pdgfr $\alpha$ is expressed only by AT-MSCs and is not present on committed preadipocytes (Cawthorn et al. 2012). Our results indicate evidence for a large population of $\mathrm{Pdgfr}{ }^{+} \mathrm{Scal}^{+}$cells in adipose tissue in mice, even though prior reports have found these cells in bone (Houlihan et al. 2012). Obtaining a pure population of cells was important, because contamination with other SVFs (which is possible in different proportions among different genotypes/ depots) could influence the differentiation ability of the isolated cells, regardless of their GH signaling status.

A key aspect of MSC culture environment is the necessity of serum, which constitutes a basic source of nutrients, hormones, growth factors, and micronutrients that are essential for maintaining proper properties and growth conditions. The choice of serum has significant importance in culturing MSCs (Shahdadfar et al. 2005). A culture media with a concentration of $10 \%$ FBS contains $\sim 6 \mathrm{ng} / \mathrm{ml} \mathrm{GH}$ and $7 \mathrm{ng} / \mathrm{ml}$ insulin-like growth factor 1 (IGF1), which is sufficient to impair the effects of exogenous added GH and IGF1 (Kurtz et al. 1985, Cool et al. 2005). To specifically address the GH effect on adipogenesis and at the same time to avoid any unspecific effects of the GH present in serum, we used cells that lack $\mathrm{GH}$ action. We report an increased level of adipogenesis of cells that lack GH action, as measured by the gene expression of adipocyte-related markers (Ppar $\gamma$, Fabp4, and adiponectin) and lipid accumulation. Moreover, we observed decreased adipogenesis of the cells that have an extra copy of bovine GH, which suggests a negative paracrine effect of GH on the adipogenesis of AT-MSCs. $P p a r \gamma$, a member of the nuclear receptor superfamily, is both necessary and sufficient for adipogeneis (Rosen \& MacDougald 2006). Its expression rapidly increases after the induction of adipogenesis, and maximal levels of expression are attained in mature adipocytes (Gregoire et al. 1998). During the terminal phase of

Published by Bioscientifica Ltd 

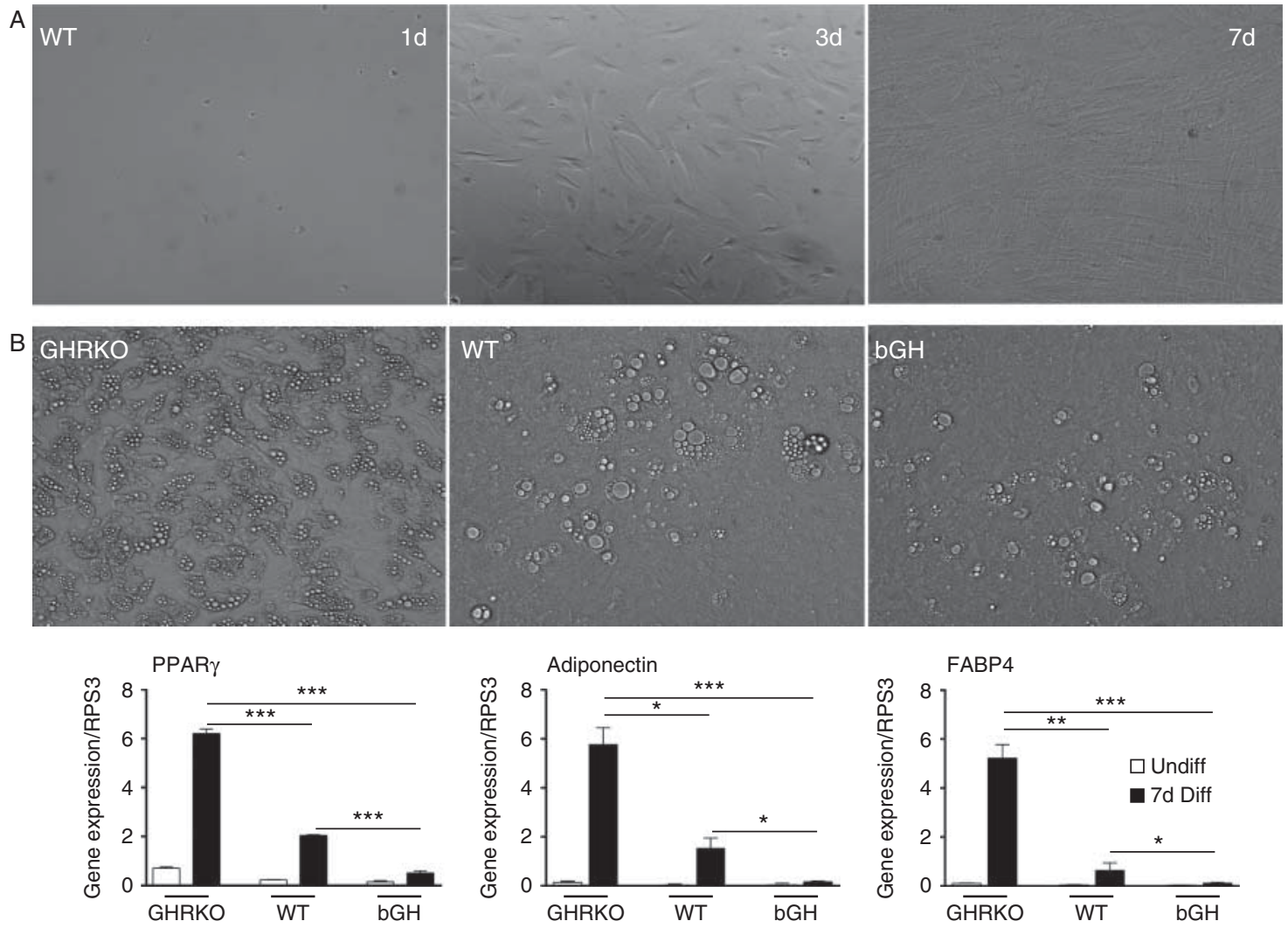

\section{Figure 4}

Phenotypic appearance of sc WT AT-MSCs after isolation (A) and comparison of the adipogenic properties between GHRKO, bGH, and WT cells (B). (A) In vitro appearance of sc WT AT-MSCs at 1, 3, and 7 days after FACS isolation. The cells adhered to the plastic surface and presented a round form at 1 day after isolation. At 3 and 7 days, the cells started to elongate, to acquire a characteristic fusiform appearance, and to divide. (B) The adipogenesis of sc AT-MSCs from GHRKO, bGH, and WT mice at
7 days of differentiation. GHRKO cells achieved a higher differentiation, whereas bGH cells showed an impaired differentiation, as quantified by lipid accumulation and the gene expression of the adipogenic markers. Data are presented as means \pm s.E.M. Undiff, undifferentiated; 7d Diff, 7 days differentiated; WT, wild-type littermate control mice; GHRKO, growth hormone receptor knockout mice; bGH, bovine growth hormone transgenic mice. ${ }^{*} P<0.05,{ }^{*} P \leq 0.01,{ }^{*} * P \leq 0.001 .10 \times$ magnification. differentiation, adipocytes synthetize FABP4, a protein directly related to lipid metabolism, and adiponectin, a classical adipokine (Lowe et al. 2011).

Another typical sign of adipogenesis is the accumulation of intracellular lipid droplets. In vivo, white mature adipocytes contain a large, single lipid droplet, which displaces the nucleus to the periphery. Lipid accumulation in vitro may not necessarily replicate lipid accumulation seen in vivo, but a tendency toward larger and fewer lipid droplets is evident in old cultures of mature adipocytes. Morphologically, brown adipocytes differ from white adipocytes in terms of their multilocular appearance, which is caused by their numerous small lipid droplets (Lee et al. 2013). Of note, in the present study, the lipid droplet morphology in GHRKO cells was closer to brown than to white adipocyte appearance, which raises the question of whether the function is similar. In fact, an argument for a potential increase in the metabolic activity of sc fat in GHRKO mice comes from the observation that GHRKO mice, even when they are obese, are extremely insulin-sensitive (List et al. 2011, Sackmann-Sala et al. 2014). This is also supported by human studies that showed that individuals who carry mutations in the GHR gene and lack GH signaling, although they are often obese, are protected from metabolic dysfunction (GuevaraAguirre et al. 2011). However, this model is not necessarily valid in subjects with adult-onset $\mathrm{GH}$ deficiency who are not protected against type 2 diabetes or metabolic syndrome. Thus, it seems that the time point during the lifespan when $\mathrm{GH}$ action is disrupted is of major importance with regard to its metabolic consequences.

$\mathrm{GH}$ excess in mice and humans has been shown to decrease fat and to increase lean mass but also to induce insulin resistance (Vijayakumar et al. 2011, Olarescu et al.

Published by Bioscientifica Ltd 
A
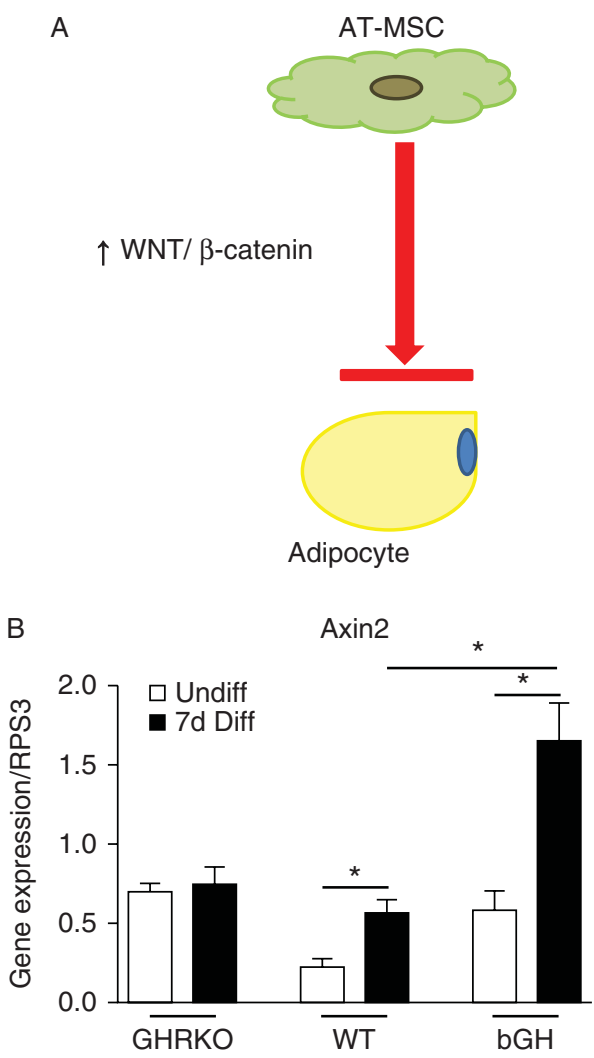

Figure 5

Activation of Wnt/ $\beta$-catenin signaling decreases adipogenesis of MSCs (A). Axin2, a marker of $\mathrm{Wnt} / \beta$-catenin activation, is increased in mature sc-bGH adipocytes, which suggests that the decreased adipogenetic potential of these cells might be attributed to increased Wnt/ $\beta$-catenin activity (B). Data are presented as means \pm s.E.M. Undiff, undifferentiated; $7 \mathrm{~d}$ Diff, 7 days differentiated; WT, wild-type littermate control mice; GHRKO, growth hormone receptor knockout mice; bGH, bovine growth hormone transgenic mice. ${ }^{*} P<0.05$. A full colour version of this figure is available at http://dx.doi.org/10.1530/JOE-15-0012.

2012). As has been suggested by previous investigations (Berryman et al. 2004, 2010, Jara et al. 2014), we confirm that the percentage of fat mass is markedly elevated in GHRKO and significantly decreased in bGH relative to WT male mice at 4 months of age. Furthermore, there is clear evidence in the literature that adipose tissue is impacted in a depot-specific manner in mice with altered GH signaling (Berryman et al. 2004, 2011). In this respect, the accumulation of fat in GHRKO is not uniform and has been shown to localize mainly to the sc depot, whereas intra-abdominal depots are proportional in size to those of WT (Berryman et al. 2010). The present study provides a possible mechanism for explaining the increased sc fat depot in GHRKO mice, which could be a result of increased adipogenesis. In accordance with this, recent studies have demonstrated that GH action is AT depot-specific (Berryman et al. 2011, Lubbers et al. 2013, Sackmann-Sala et al. 2014, Stout et al. 2014). This may explain the differences in immune cell content, adipokine production, cellular composition, cellular senescence, plasticity, and extracellular matrix content among different AT depots that finally lead to various metabolic outcomes.

In addition to the known lipolytic activity of $\mathrm{GH}$, the inhibition of adipogenesis, as shown in the present study, may contribute to the systemic insulin resistance that is associated with GH excess. Both processes lead to increased circulating free fatty acids (FFAs) either via the release of FFAs from AT through lipolysis or via the incapacity to store excess FFAs in newly recruited adipocytes because of the diminished capacity of differentiation. Recent evidence has unequivocally demonstrated a role of FFA and ectopic lipid accumulation in the pathogenesis of insulin resistance in muscles and the liver (Hocking et al. 2013, Shulman 2014).

Importantly, we observed depot-specific differences in the ability of sorted AT-MSCs to differentiate in a medium containing IBMX, dexamethasone, indomethacin, and insulin, with the sc depot being the only depot to fully achieve adipogenesis. Regional differences in MSC replication, differentiation, subtype abundance, susceptibility to apoptosis or senescence, and capacity for adipogenesis, even when they originate from the same individual, have been previously described (Tchkonia et al. 2013). The regional differences are heritable over many cell generations, which suggests that the multipotentiality of MSCs is epigenetically restricted (Reinisch et al. 2014).

In terms of adipogenesis, we also found that GH-induced intracellular signaling may activate the canonical WNT/ $\beta$-catenin pathway in AT-MSCs, a process that could explain the negative influence of $\mathrm{GH}$ on adipogenesis. Indeed, several reports have implicated WNT/ $\beta$-catenin as a molecular switch that, when activated, represses adipogenesis (Christodoulides et al. 2009). Furthermore, the activation of Wnt/ $\beta$-catenin leads to impaired insulin stimulation of glucose uptake in mature adipocytes (Gustafson \& Smith 2010), which could represent yet another mechanism for explaining GH-induced insulin resistance (i.e., GH's diabetogenic effect).

The present study has some limitations. First, the experiments were performed only in 4-month-old male mice, which did not allow us to evaluate age- and sex-related influences. Although differences in body composition between male and female mice have been demonstrated (Berryman et al. 2010), no effect of estrogens

Published by Bioscientifica Ltd 
on the in vitro differentiation potential of AT-MSCs has been reported (Veronesi et al. 2014). On the other hand, we decided to perform the present study in relatively young animals to account for previously reported agerelated variations in MSC properties (Kim et al. 2012). Second, we did not evaluate the possible effects IGF1, which is present in FBS or is produced upon GH stimulation. However, the differences in the adipogeneis observed in the present study were not a result of IGF1 action because GHRKO cells, which lack GH signaling, may eventually produce less IGF1 that would act in a paracrine manner and favor adipogenesis. Moreover, bGH cells showed impaired adipogenesis in the present study, an opposite effect of the pro-adipogenic action of IGF1 that has been described in the literature (Scavo et al. 2004). Third, the results regarding the activation of the canonical WNT/ $\beta$-catenin pathway by GH should be considered with caution, because they were based on the measurement of a single WNT/ $\beta$-catenin signaling marker, namely, Axin2. Further studies to demonstrate that the inhibition of $\mathrm{WNT} / \beta$-catenin activation in bGH cells leads to an increased adipogenesis are needed before a definite conclusion can be made. Finally, although we isolated AT-MSCs using two specific surface antibodies in an attempt to select cells that were at the same stage of differentiation, we cannot rule out that prior in vivo exposure did not influence the intrinsic properties of the isolated cells.

In conclusion, the present results suggest that GH diminishes the amount of AT by altering the adipogenesis of AT-MSCs. Consequently, a reduced AT expandability potential might represent a novel mechanism for further explaining GH-induced insulin resistance.

\section{Declaration of interest}

The authors declare that there is no conflict of interest that could be perceived as prejudicing the impartiality of the research reported.

\section{Funding}

Part of this work was supported by the NIH (grant number P01AG031736), the State of Ohio's Eminent Scholar Program, which includes a gift from Milton and Lawrence Goll, the AMVETS, the Diabetes Institute at Ohio University, and the Nathalia and Knut Juul Christiansens Foundation (Oslo, Norway).

\section{Acknowledgements}

We thank Mrs Michelle Pate, Department of Chemical and Biomolecular Engineering, Ohio University, for her technical assistance with FACS.

\section{References}

Berryman DE, List EO, Coschigano KT, Behar K, Kim JK \& Kopchick JJ 2004 Comparing adiposity profiles in three mouse models with altered GH signaling. Growth Hormone \& IGF Research 14 309-318. (doi:10.1016/j. ghir.2004.02.005)

Berryman DE, List EO, Palmer AJ, Chung MY, Wright-Piekarski J, Lubbers E, O'Connor P, Okada S \& Kopchick JJ 2010 Two-year body composition analyses of long-lived GHR null mice. Journals of Gerontology. Series A, Biological Sciences and Medical Sciences 65 31-40. (doi:10.1093/gerona/ glp175)

Berryman DE, List EO, Sackmann-Sala L, Lubbers E, Munn R \& Kopchick JJ 2011 Growth hormone and adipose tissue: beyond the adipocyte. Growth Hormone \& IGF Research 21 113-123. (doi:10.1016/j.ghir.2011. 03.002)

Cawthorn WP, Scheller EL \& MacDougald OA 2012 Adipose tissue stem cells meet preadipocyte commitment: going back to the future. Journal of Lipid Research 53 227-246. (doi:10.1194/jlr.R021089)

Christodoulides C, Lagathu C, Sethi JK \& Vidal-Puig A 2009 Adipogenesis and WNT signalling. Trends in Endocrinology and Metabolism 20 16-24. (doi:10.1016/j.tem.2008.09.002)

Clarkson RW, Chen CM, Harrison S, Wells C, Muscat GE \& Waters MJ 1995 Early responses of trans-activating factors to growth hormone in preadipocytes: differential regulation of CCAAT enhancer-binding protein-beta (C/EBP $\beta)$ and C/EBP delta. Molecular Endocrinology 9 108-120. (doi:10.1210/mend.9.1.7760844)

Cool SM, Grunert M, Jackson R, Li H, Nurcombe V \& Waters MJ 2005 Role of growth hormone receptor signaling in osteogenesis from murine bone marrow progenitor cells. Biochemical and Biophysical Research Communications 338 1048-1058. (doi:10.1016/j.bbrc.2005. 10.035)

Corin RE, Guller S, Wu KY \& Sonenberg M 1990 Growth hormone and adipose differentiation: growth hormone-induced antimitogenic state in 3T3-F442A preadipose cells. PNAS 87 7507-7511. (doi:10.1073/pnas. 87.19.7507)

Doglio A, Dani C, Grimaldi P \& Ailhaud G 1986 Growth hormone regulation of the expression of differentiation-dependent genes in preadipocyte Ob1771 cells. Biochemical Journal 238 123-129.

Flint DJ, Binart N, Boumard S, Kopchick JJ \& Kelly P 2006 Developmental aspects of adipose tissue in GH receptor and prolactin receptor gene disrupted mice: site-specific effects upon proliferation, differentiation and hormone sensitivity. Journal of Endocrinology 191 101-111. (doi:10.1677/joe.1.06939)

Green H, Morikawa M \& Nixon T 1985 A dual effector theory of growthhormone action. Differentiation; Research in Biological Diversity 29 195-198. (doi:10.1111/j.1432-0436.1985.tb00316.x)

Gregoire FM, Smas CM \& Sul HS 1998 Understanding adipocyte differentiation. Physiological Reviews 78 783-809.

Guevara-Aguirre J, Balasubramanian P, Guevara-Aguirre M, Wei M, Madia F, Cheng CW, Hwang D, Martin-Montalvo A, Saavedra J, Ingles S et al. 2011 Growth hormone receptor deficiency is associated with a major reduction in pro-aging signaling, cancer, and diabetes in humans. Science Translational Medicine 3 70ra13. (doi:10.1126/scitranslmed. 3001845)

Gustafson B \& Smith U 2010 Activation of canonical wingless-type MMTV integration site family (Wnt) signaling in mature adipocytes increases $\beta$-catenin levels and leads to cell dedifferentiation and insulin resistance. Journal of Biological Chemistry 285 14031-14041. (doi:10.1074/jbc.M110.102855)

Hansen LH, Madsen B, Teisner B, Nielsen JH \& Billestrup N 1998 Characterization of the inhibitory effect of growth hormone on primary preadipocyte differentiation. Molecular Endocrinology 12 1140-1149. (doi:10.1210/mend.12.8.0154)

Hausman GJ \& Martin RJ 1989 The influence of human growth hormone on preadipocyte development in serum-supplemented and serum-free

Published by Bioscientifica Ltd. http://joe.endocrinology-journals.org DOI: 10.1530/JOE-15-0012
() 2015 Society for Endocrinology Printed in Great Britain 
cultures of stromal-vascular cells from pig adipose tissue. Domestic Animal Endocrinology 6 331-337. (doi:10.1016/0739-7240(89)90027-1)

Hocking S, Samocha-Bonet D, Milner KL, Greenfield JR \& Chisholm DJ 2013 Adiposity and insulin resistance in humans: the role of the different tissue and cellular lipid depots. Endocrine Reviews 34 463-500. (doi:10.1210/er.2012-1041)

Houlihan DD, Mabuchi Y, Morikawa S, Niibe K, Araki D, Suzuki S, Okano H \& Matsuzaki Y 2012 Isolation of mouse mesenchymal stem cells on the basis of expression of Sca-1 and PDGFR $\alpha$. Nature Protocols 7 2103-2111. (doi:10.1038/nprot.2012.125)

Jara A, Benner CM, Sim D, Liu X, List EO, Householder LA, Berryman DE \& Kopchick JJ 2014 Elevated systolic blood pressure in male GH transgenic mice is age dependent. Endocrinology 155 975-986. (doi:10.1210/en.2013-1899)

Jorgensen AP, Fougner KJ, Ueland T, Gudmundsen O, Burman P, Schreiner T \& Bollerslev J 2011 Favorable long-term effects of growth hormone replacement therapy on quality of life, bone metabolism, body composition and lipid levels in patients with adult-onset growth hormone deficiency. Growth Hormone \& IGF Research 21 69-75. (doi:10.1016/j.ghir.2011.01.001)

Kim M, Kim C, Choi YS, Kim M, Park C \& Suh Y 2012 Age-related alterations in mesenchymal stem cells related to shift in differentiation from osteogenic to adipogenic potential: implication to age-associated bone diseases and defects. Mechanisms of Ageing and Development 133 215-225. (doi:10.1016/j.mad.2012.03.014)

Kurtz A, Hartl W, Jelkmann W, Zapf J \& Bauer C 1985 Activity in fetal bovine serum that stimulates erythroid colony formation in fetal mouse livers is insulinlike growth factor I. Journal of Clinical Investigation 76 1643-1648. (doi:10.1172/JCI112149)

Lee P, Swarbrick MM \& Ho KK 2013 Brown adipose tissue in adult humans: a metabolic renaissance. Endocrine Reviews 34 413-438. (doi:10.1210/ er.2012-1081)

List EO, Palmer AJ, Berryman DE, Bower B, Kelder B \& Kopchick JJ 2009 Growth hormone improves body composition, fasting blood glucose, glucose tolerance and liver triacylglycerol in a mouse model of dietinduced obesity and type 2 diabetes. Diabetologia 52 1647-1655. (doi:10.1007/s00125-009-1402-z)

List EO, Sackmann-Sala L, Berryman DE, Funk K, Kelder B, Gosney ES, Okada S, Ding J, Cruz-Topete D \& Kopchick JJ 2011 Endocrine parameters and phenotypes of the growth hormone receptor gene disrupted (GHR - /-) mouse. Endocrine Reviews 32 356-386. (doi:10.1210/er.2010-0009)

Lowe CE, O'Rahilly S \& Rochford JJ 2011 Adipogenesis at a glance. Journal of Cell Science 124 2681-2686. (doi:10.1242/jcs.079699)

Lubbers ER, List EO, Jara A, Sackman-Sala L, Cordoba-Chacon J, Gahete MD, Kineman RD, Boparai R, Bartke A, Kopchick JJ et al. 2013 Adiponectin in mice with altered GH action: links to insulin sensitivity and longevity? Journal of Endocrinology 216 363-374. (doi:10.1530/JOE-12-0505)

Moller N \& Jorgensen JO 2009 Effects of growth hormone on glucose, lipid, and protein metabolism in human subjects. Endocrine Reviews 30 152-177. (doi:10.1210/er.2008-0027)

Morikawa M, Nixon T \& Green H 1982 Growth hormone and the adipose conversion of 3T3 cells. Cell 29 783-789. (doi:10.1016/00928674(82)90440-8)

Olarescu NC, Ueland T, Lekva T, Dahl TB, Halvorsen B, Aukrust P \& Bollerslev J 2012 Adipocytes as a source of increased circulating levels of nicotinamide phosphoribosyltransferase/visfatin in active acromegaly. Journal of Clinical Endocrinology and Metabolism 97 1355-1362. (doi:10.1210/jc.2011-2417)

Pittenger MF, Mackay AM, Beck SC, Jaiswal RK, Douglas R, Mosca JD, Moorman MA, Simonetti DW, Craig S \& Marshak DR 1999 Multilineage potential of adult human mesenchymal stem cells. Science $\mathbf{2 8 4}$ 143-147. (doi:10.1126/science.284.5411.143)

Reinisch A, Etchart N, Thomas D, Hofmann NA, Fruehwirth M, Sinha S, Chan CK, Senarath-Yapa K, Seo E, Wearda T et al. 2014 Epigenetic and in vivo comparison of diverse MSC sources reveals an endochondral signature for human hematopoietic niche formation. Blood $\mathbf{1 2 5}$ 249-260. (doi:10.1182/blood-2014-04-572255)

Richter HE, Albrektsen T \& Billestrup N 2003 The role of signal transducer and activator of transcription 5 in the inhibitory effects of GH on adipocyte differentiation. Journal of Molecular Endocrinology 30 139-150. (doi:10.1677/jme.0.0300139)

Rosen ED \& MacDougald OA 2006 Adipocyte differentiation from the inside out. Nature Reviews. Molecular Cell Biology 7 885-896. (doi:10.1038/nrm2066)

Rosen ED \& Spiegelman BM 2014 What we talk about when we talk about fat. Cell 156 20-44. (doi:10.1016/j.cell.2013.12.012)

Ross SE, Hemati N, Longo KA, Bennett CN, Lucas PC, Erickson RL \& MacDougald OA 2000 Inhibition of adipogenesis by Wnt signaling. Science 289 950-953. (doi:10.1126/science.289.5481.950)

Sackmann-Sala L, Berryman DE, Lubbers ER, Zhang H, Vesel CB, Troike KM, Gosney ES, List EO \& Kopchick JJ 2014 Age-related and depot-specific changes in white adipose tissue of growth hormone receptor-null mice. Journals of Gerontology. Series A, Biological Sciences and Medical Sciences 69 34-43. (doi:10.1093/gerona/glt110)

Scavo LM, Karas M, Murray M \& Leroith D 2004 Insulin-like growth factor-I stimulates both cell growth and lipogenesis during differentiation of human mesenchymal stem cells into adipocytes. Journal of Clinical Endocrinology and Metabolism 89 3543-3553. (doi:10.1210/jc.2003031682)

Shahdadfar A, Fronsdal K, Haug T, Reinholt FP \& Brinchmann JE 2005 In vitro expansion of human mesenchymal stem cells: choice of serum is a determinant of cell proliferation, differentiation, gene expression, and transcriptome stability. Stem Cells 23 1357-1366. (doi:10.1634/ stemcells.2005-0094)

Shang CA \& Waters MJ 2003 Constitutively active signal transducer and activator of transcription 5 can replace the requirement for growth hormone in adipogenesis of 3T3-F442A preadipocytes. Molecular Endocrinology 17 2494-2508. (doi:10.1210/me.2003-0139)

Shulman GI 2014 Ectopic fat in insulin resistance, dyslipidemia, and cardiometabolic disease. New England Journal of Medicine $\mathbf{3 7 1}$ 1131-1141. (doi:10.1056/NEJMra1011035)

Stewart WC, Baugh JE Jr, Floyd ZE \& Stephens JM 2004 STAT 5 activators can replace the requirement of FBS in the adipogenesis of 3T3-L1 cells. Biochemical and Biophysical Research Communications 324 355-359. (doi:10.1016/j.bbrc.2004.09.053)

Stout MB, Tchkonia T, Pirtskhalava T, Palmer AK, List EO, Berryman DE, Lubbers ER, Escande C, Spong A, Masternak MM et al. 2014 Growth hormone action predicts age-related white adipose tissue dysfunction and senescent cell burden in mice. Aging 6 575-586.

Tchkonia T, Thomou T, Zhu Y, Karagiannides I, Pothoulakis C, Jensen MD \& Kirkland JL 2013 Mechanisms and metabolic implications of regional differences among fat depots. Cell Metabolism 17 644-656. (doi:10.1016/j.cmet.2013.03.008)

Veronesi F, Pagani S, Della Bella E, Giavaresi G \& Fini M 2014 Estrogen deficiency does not decrease the in vitro osteogenic potential of rat adipose-derived mesenchymal stem cells. Age 36 9647. (doi:10.1007/ s11357-014-9647-y)

Vijayakumar A, Yakar S \& Leroith D 2011 The intricate role of growth hormone in metabolism. Frontiers in Endocrinology 2 32. (doi:10.3389/ fendo.2011.00032)

Wabitsch M, Hauner H, Heinze E \& Teller WM 1995 The role of growth hormone/insulin-like growth factors in adipocyte differentiation. Metabolism: Clinical and Experimental 44 45-49. (doi:10.1016/ 0026-0495(95)90220-1)

Wabitsch M, Braun S, Hauner H, Heinze E, Ilondo MM, Shymko R, De Meyts P \& Teller WM $1996 a$ Mitogenic and antiadipogenic properties of human growth hormone in differentiating human adipocyte precursor cells in primary culture. Pediatric Research 40 450-456. (doi:10.1203/ 00006450-199609000-00014)

Wabitsch M, Heinze E, Hauner H, Shymko RM, Teller WM, De Meyts P \& Ilondo MM $1996 b$ Biological effects of human growth hormone in rat 
adipocyte precursor cells and newly differentiated adipocytes in primary culture. Metabolism: Clinical and Experimental 45 34-42. (doi:10.1016/S0026-0495(96)90197-3)

Yarwood SJ, Sale EM, Sale GJ, Houslay MD, Kilgour E \& Anderson NG 1999 Growth hormone-dependent differentiation of 3T3-F442A preadipocytes requires Janus kinase/signal transducer and activator of transcription but not mitogen-activated protein kinase or p70 S6 kinase signaling. Journal of Biological Chemistry 274 8662-8668. (doi:10.1074/ jbc.274.13.8662)

Zhou Y, Xu BC, Maheshwari HG, He L, Reed M, Lozykowski M, Okada S, Cataldo L, Coschigamo K, Wagner TE et al. 1997 A mammalian model for Laron syndrome produced by targeted disruption of the mouse growth hormone receptor/binding protein gene (the Laron mouse). PNAS 94 13215-13220. (doi:10.1073/pnas.94.24.13215)

Zhao L, Wang A, Corl BA \& Jiang H 2014 Effect of growth hormone on the differentiation of bovine preadipocytes into adipocytes and the role of the signal transducer and activator of transcription 5b. Journal of Animal Science 92 1958-1967. (doi:10.2527/jas.2013-7113)

Zuk PA, Zhu M, Ashjian P, De Ugarte DA, Huang JI, Mizuno H, Alfonso ZC, Fraser JK, Benhaim P \& Hedrick MH 2002 Human adipose tissue is a source of multipotent stem cells. Molecular Biology of the Cell $\mathbf{1 3}$ 4279-4295. (doi:10.1091/mbc.E02-02-0105)

Received in final form 16 April 2015

Accepted 5 May 2015

Accepted Preprint published online 5 May 2015
Published by Bioscientifica Ltd. 